\title{
Pengelolaan Bank Sampah di Kota Probolinggo
}

\author{
Prisa Ambar Shentika \\ Fakultas Ekonomi, Universitas Negeri Malang \\ Email: shenprisa@gmail.com
}

\begin{abstract}
A programme of reducing garbage leads the community, government, and corporate field to attentively limit the trash heap, recycling, and reusing garbage through the efficient and well-regulated efforts commonly called $3 R$ Reduce, Reuse, Recycle. Probolinggo is the town in which developing regulate a policy of management garbage with Waste Bank by $3 R$ concepts. This research aims to find out the management and role of Waste Bank in Probolinggo. It is conducted by using qualitative descriptive research method. Data collection is obtained by using direct observation and interview to resource. The result shows that $3 R$ concepts used by waste bank in Probolinggo is carried out fairly well in working along with society particularly in sorting the garbage. Therefore, aware of environmental issues is not on government but society will cooperatively in role to protect environment. Waste bank is economically good for society beside environmentally worthwhile.
\end{abstract}

Keywords: 3R Concept, Waste Bank, Society

\section{PENDAHULUAN}

Kehidupan sehari-hari manusia tidak terlepas dari kegiatan ekonomi dan non-ekonomi. Dimana kegiatan ekonomi seperti produksi, distribusi dan konsumsi memiliki dampak positif dan negatif. Dampak positif kegiatan ekonomi merupakan sebuah cara dalam pemenuhan kebutuhan manusia sehari-hari. Kegiatan ekonomi sendiri memiliki dampak negatif terhadap lingkungan untuk saat ini dan masa yang akan datang yakni dengan munculnya sampah. Sampah merupakan hasil material dari adanya suatu proses/kegiatan. Keberadaan sampah bisa sangat mengkhawatirkan jika tidak ditangani dengan baik.

Pada masa mendatang, sampah akan menjadi masalah serius karena faktorfaktor yang menyebabkan timbulan sampah seperti jumlah penduduk, keadaan sosial ekonomi serta kemajuan teknologi diperkirakan akan mengalami pengingkatan yang signifikan (Slamet, 2000). Permasalahan tersebut timbul karena manusia kurang sadar bahwa pada kegiatan ekonomi yang mereka lakukan ada aspek-aspek pendukung lainnya yang harus diperhatikan khususnya adalah lingkungan. Jika aspek lingkungan tidak diperhatikan, sangat memungkinkan terjadinya kerusakan hingga bencana alam yang akan menghambat kegiatan perekonomian manusia.

Perlunya perubahan paradigma yang mendasar dalam pengelolaan sampah yaitu dari paradigma kumpul - angkut - buang menjadi pengolahan yang bertumpu pada pengurangan sampah dan penanganan sampah (Peraturan Pemerintah Nomor 81 Tahun 2012). Kegiatan pengurangan sampah bermakna agar masyarakat, baik pemerintah, dunia usaha maupun masyarakat luas melaksanakan kegiatan 
pembatasan timbulan sampah, pendauran ulang dan pemanfaatan kembali sampah atau yang lebih dikenal dengan sebutan Reduce, Reuse dan Recycle (3R) melalui upaya-upaya cerdas, efisien dan terprogram. Kota Probolinggo merupakan salah satu kota dimana dalam perkembangannya menerapkan kebijakan pengelolaan sampah. Hal ini dilakukan melalui program bank sampah dimana konsep 3R diterapkan.

Konsep 3R merupakan alternatif cara yang dilakukan dalam pengelolaan dan menangani masalah sampah yang menjadi permasalahan lingkungan saat ini terhadap pertumbuhan ekonomi. Bank sampah sendiri merupakan suatu lembaga dimana kegiatannya adalah menghimpun sampah dari masyarakat yang masih memiliki nilai ekonomi untuk kemudian dipilah, ditimbang, dijual dan hasil penjualannya masuk ke dalam rekening nasabah bank sampah. Bank sampah memiliki berbagai kegiatan dengan konsep 3R yang mendukung. Kegiatan tersebut menerapkan konsep 3R seperti mengurangi jumlah sampah daun-daunan kemudian diubah menjadi kompos, mendaur ulang kemasan pembungkus kopi menjadi tas dan sendok plastik yang dibuat menjadi kap lampu. Bank sampah sama seperti lembaga keuangan lainnya yang membedakan yaitu setoran yang diberikan nasabah dalam bentuk sampah. Kemudian dipilah, ditimbang dan hasil penjualannya dimasukkan ke dalam rekening nasabah. Kota Probolinggo merupakan salah satu kota yang memiliki Bank Sampah dengan konsep 3R sebagai alternatif cara dalam mengatasi dan mengelola sampah. Dengan demikian tujuan penelitian ini adalah untuk mengetahui pengelolaan bank sampah yang ada di Kota Probolinggo

\section{KAJIAN PUSTAKA \\ Definisi Bank Sampah}

Menurut Peraturan Menteri Negara Lingkungan Hidup RI Nomor 13 Tahun 2012 Bank Sampah adalah tempat pemilahan dan pengumpulan sampah yang dapat didaur ulang dan/atau diguna ulang yang memiliki nilai ekonomi. Dengan kata lain bank sampah adalah sebuah lembaga ekonomi dimana sampah menjadi alat transaksi yang digunakan dalam kegiatannya, karena berbeda dengan bank konvensional yang menggunakan uang sebagai instrumen utama maka bank sampah lebih menekankan fokusnya pada pengelolaan sampah yang menjadi permasalahan bagi lingkungan saat ini. Bank sampah dilirik sebagai alternatif cara dalam mengatasi limbah yang berlebih dari kehidupan sehari-hari untuk kemudian dirubah menjadi sesuatu yang bernilai ekonomis.

Adapun tujuan didirikannya Bank Sampah Maspro Mesra di Kota Probolinggo adalah sebagai berikut: 1) aspek Pemberdayaan yaitu memberdayakan masyarakat di semua unsur dan kalangan usia dalam mengelola sampah. 2) aspek Ekonomi Kerakyatan yaitu pemberdayaan dalam sistem menabung sampah, serta menambah lapangan kerja baru. 3) aspek Lingkungan yaitu membantu pemerintah mengurangi jumlah sampah terutama di TPS yang semakin lama menjadi gunungan sampah. Serta membantu memberikan penyuluhan kepada msyarakat dan mengubah cara pandang masyarakat dalam rangka pelestarian lngkungan. 4) aspek Sosial yaitu menciptakan rasa peduli dan gotong royong dalam mengelolah sampah. 5) aspek Pendidikan yaitu memberikan pengetahuan lingkungan kepada masyarakat dan siswa untuk mengolah sampah agar lebih bermanfaat. 


\section{Konsep 3R (Reduce, Reuse dan Recycle)}

Konsep 3R (Reduce, Reuse dan Recycle) adalah sebuah metode baru dalam pengelolaan sampah. Dimana 3R tersebut adalah mengurangi segala sesuatu yang mengakibatkan sampah (reduce), menggunakan kembali sampah yang masih bisa digunakan kembali (reuse) dan mengolah kembali/ daur ulang sampah menjadi barang atau produk baru yang bermanfaat (recycle). Penerapan sistem 3R atau reuse, reduce, dan recycle menjadi salah satu solusi pengelolaan sampah di samping mengolah sampah menjadi kompos atau meanfaatkan sampah menjadi sumber listrik (PLTSa; Pembangkit Listrik Tenaga Sampah).

\section{Reduce}

Reduce yaitu mengurangi segala sesuatu yang menyebabkan timbulnya sampah, contohnya ketika belanja membawa kantong/keranjang dari rumah, mengurangi kemasan yang tidak perlu, menggunakan kemasan yang dapat didaur ulang, misalnya bungkus nasi menggunakan daun pisang atau daun jati.

Menurut UPT. PSL di Kota Probolinggo kegiatan reduce dapat dilakukan sehari-hari seperti:

1. Pilih produk dengan kemasan yang dapat didaur ulang.

2. Hindari memakai dan membeli produk yang menghasilkan sampah dalam jumlah besar seperti penggunaan tas kresek.

3. Gunakan produk yang dapat diisi ulang (refill). Misalnya alat tulis yang bisa diisi ulang kembali)

4. Maksimumkan penggunaan alat-alat penyimpan elektronik yang dapat dihapus dan ditulis kembali.

5. Kurangi penggunaan bahan sekali pakai.

6. Gunakan kedua sisi kertas untuk penulisan dan fotokopi.

7. Hindari membeli dan memakai barang-barang yang kurang perlu.

\section{Reuse}

Menurut UPT. PSL di Kota Probolinggo kegiatan reuse adalah kegiatan penggunaan kembali sampah yang masing dapat digunakan baik untuk fungsi yang sama maupun fungsi lain, contohnya berupa botol bekas minuman dirubah fungsi jadi tempat minyak goreng, ban bekas, dimodifikasi jadi kursi, pot bunga.

Kegiatan Reuse menurut UPT. PSL Kota Probolinggo dapat dilakukan sehari-hari seperti:

1. Pilihlah wadah, kantong atau benda yang dapat digunakan beberapa kali atau berulang-ulang. Misalnya, pergunakan serbet dari kain dari pada menggunakan tissu, menggunakan baterai yang dapat di charge kembali.

2. Gunakan kembali wadah atau kemasan yang telah kosong untuk fungsi yang sama atau fungsi lainnya. Misalnya botol bekas minuman digunakan kembali menjadi tempat minyak goreng.

3. Gunakan alat-alat penyimpan elektronik yang dapat dihapus dan ditulis kembali.

4. Gunakan sisi kertas yang masih kosong untuk menulis.

5. Gunakan email (surat elektronik) untuk berkirim surat.

6. Jual atau berikan sampah yang terpilah kepada pihak yang memerlukan.

7. Mengumpulkan pakaian yang masih pantas dipakai untuk disumbangkan kepada yang membutuhkan.

8. Menghemat makanan dan tidak menyisakan makanan. 


\section{Recycle}

Recycle adalah salah satu dari bagian konsep 3R dimana kegiatannya yaitu mengolah kembali (daur ulang) sampah menjadi barang atau produk baru yang bermanfaat. Menurut UPT. PSL Kota Probolinggo kegiatan reduce dapat dilakukan sehari-hari seperti:

1. Pilih produk dan kemasan yang dapat didaur ulang dan mudah terurai.

2. Olah sampah kertas menjadi kertas atau karton kembali.

3. Lakukan pengolahan sampah organik menjadi kompos.

4. Lakukan pengolahan sampah non organik menjadi barang yang bermanfaat.

5. Berpartisipasi dalam mendaur ulang kertas ataupun botol plastik ataupun kaleng.

6. Mengumpulkan dan membuang barang yang tidak dipakai di pasar loak.

\section{Definisi Partisipasi Masyarakat}

Partisipasi masyarakat adalah proses aktif yang dilakukan masyarakat dalam mewujudkan tujuan atau target yang ingin dicapai. Partisipasi ada yang bersifat aktif dan pasif (Sondang, 1985). Dimana jenis partisipasi yaitu:

1. Partisipasi pasif dapat diartikan bahwa dalam sikap, perilaku dan tindakannya tidak melakukan hal-hal yang mengakibatkan terhambatnya suatu kegiatan pembangunan.

2. Partisipasi aktif dapat diartikan dengan memanfaatkan lembaga-lembaga sosial dan politik yang ada di masyarakat sebagai saluran aspirasinya. Menunjukkan adanya kesadaran bermasyarakat dan bernegara yang tinggi kepada pimpinan, tokoh masyarakat, baik yang sifatnya formal maupun informal; Memenuhi kewajiban sebagai warga negara yang bertanggung jawab seperti membayar pajak secara jujur serta berkewajiban lainnya; ketaatan kepada berbagai peraturan perundang-undangan yang berlaku dan; kerelaan melakukan pengorbanan yang dituntut oleh pembangunan demi kepentingan bersama yang luas dan penting.

\section{Jenis-jenis partisipasi}

Sementara Cohen dan Uphof dalam Ndraha (1990) menguraikan bentukbentuk partisipasi yang terbagi dalam empat bentuk, yaitu: a) Partisipasi dalam pembuatan keputusan (participation in decision making). Partisipasi ini terutama berkaitan dengan penentuan alternatif dengan masyarakat yang berkaitan dengan gagasan atau ide yang menyangkut kepentingan bersama. Dalam partisipasi ini masyarakat menuntut untuk ikut menentukan arah dan orientasi pembangunan. b) partisipasi dalam pelaksanaan (participation in implementation). Partisipasi pada tahap ini maksudnya adalah pelibatan seseorang pada tahap penyusunan rencana dan strategi dalam penyusunan kepanitian dan anggaran pada suatu kegiatan/proyek. c) Partisipasi dalam menerima manfaat (participation in benefits) d) Partisipasi dalam pengambilan manfaat. Partisipasi ini tidak lepas dari hasil pelaksanaan. Partisipasi dalam evaluasi (participation in evaluation).

\section{Bentuk-bentuk partisipasi}

Menurut Ericson dalam Slamet (1994) bentuk partisipasi masyarakat dalam pembangunan terbagi atas 3 tahap, yaitu: a) Partisipasi di dalam tahap perencanaan (idea planing stage). Partisipasi pada tahap ini maksudnya adalah pelibatan seseorang pada tahap penyusunan rencana dan strategi dalam penyusunan kepanitian dan anggaran pada suatu kegiatan/proyek. b) Partisipasi di dalam tahap 
pelaksanaan (implementation stage). Partisipasi pada tahap ini maksudnya adalah pelibatan seseorang pada tahap pelaksanaan pekerjaan suatu proyek. c) Partisipasi di dalam pemanfaatan (utilitazion stage). Partisipasi pada tahap ini maksudnya adalah pelibatan seseorang pada tahap pemanfaatan suatu proyeksetelah proyek tersebut selesai dikerjakan.

\section{METODE PENELITIAN}

Penelitian ini menggunakan metode penelitian kualitatif dimana suatu penelitian ilmiah yang bertujuan untuk memahami suatu fenomena dalam konteks sosial secara alamiah dengan mengedepankan proses interaksi komunikasi yang mendalam antara peneliti dengan fenomena yang diteliti (Herdiansyah, 2010).

Peneliti berusaha untuk lebih mengeksplorasi pengelolaan bank sampah di Kota Probolinggo dimana menerapkan konsep 3R. Dalam penelitian ini penulis menggunakan pendekatan kualitatif deskriptif karena peneliti mencoba untuk mengungkap dan menggambarkan yang terjadi dalam ruang lingkup masyarakat khususnya di Kota Probolinggo yang menjadi objek penelitian. Tahap-tahap analisis data dalam penelitian ini yaitu:

\section{Reduksi data}

Hal ini dilakukan melalui proses pemilahan, pemusatan perhatian pada penyederhanaan, pengabstrakkan, dan transformasi data yang muncul dari catatancatatan yang diperoleh peneliti dari lapangan. Peneliti melakukan wawancara dengan mencocokkan informasi dari berbagai narasumber seperti dari nasabah bank sampah Bunda Peduli, Pokmas Indah serta Melati Berseri.

\section{Penyajian data}

Dari penelitian ini, penulis akan menyajikan dan memperlihatkan sekumpulan informasi yang memungkinkan penarikan kesimpulan dan pengambilan tindakan yang akan dilakukan. Diantaranya hasil wawancara kepada sumber data dengan menggunakan recorder yaitu nasabah bank sampah, nasabah bank sampah serta UPT. PSL Kota Probolinggo.

\section{Penarikan Kesimpulan}

Menarik kesimpulan merupakan kegiatan untuk mencari makna dari data yang dikumpulkan sejak awal melakukan pencarian dan pengumpulan data. Peneliti disini nantinya akan mencoba mengungkapkan bagaimana pengelolaan bank sampah di Kota Probolinggo.

\section{HASIL DAN PEMBAHASAN}

Konsep Bank Sampah Maspro Mesra di Kota Probolinggo menerapkan metode 3R yaitu Reduce (mengurangi segala sesuau yang menyebabkan timbulnya sampah), Reuse (menggunakan ulang kembali sampah secara langsung), Recycle (memanfaatkan kembali sampah setelah mengalami prose pengolahan). Prinsip bank sampah di Kota Probolinggo sama dengan tabungan pada umumnya tetapi yang membedakan adalah bentuk simpanannya yaitu berupa sampah yang masih memiliki nilai ekonomi. Keanggotaan bank sampah terdiri dari perorangan dan kelompok masyarakat pengumpul sampah. Dimana dalam pengumpulannyaa anggota dapat menyetor sampah dalam jumlah minimal lima sak sekali setor. Penyetoran sendiri dapat dilakukan oleh anggota atau pun diambil oleh petugas pada saat jam dan hari kerja. Untuk penarikkan rekening di bank Sampah Maspro 
Mesra dapat dilakukan setelah tiga bulan nasabah menabung atau jumlah tabungan nasabah telah mencapai minimal sebesar seratus ribu rupiah.

Dalam pelaksanaannya pengelola Bank Sampah Maspro Mesra melaksanakan dua jenis tabungan yakni tabungan individu dan tabungan kolektif. Pada awal pembentukannya Bank Sampah Maspro Mesra mendapatkan pendampingan dari Bank Danamon Kota Probolinggo sebagai salah satu bentuk CSR (Coorporate Social Ressponsibility). Selain itu pengurus bank sampah Maspro Mesra juga mencari link-link sebagai penerima hasil sampah anorganik yang masuk untuk kemudian dijual dan hasil penjualannya yang masuk ke dalam buku tabungan masyarakat.

Bank Sampah Maspro Mesra menerima sampah dalam dua jenis yaitu sampah organik dan sampah anorganik. Dimana sampah organik biasanya terdiri dari sampah daun-daunan, ranting, pohon, kertas dan lain dikelola dan dilakukan pencacahan dengan mesin pencacah yang telah difasilitasi oleh Pemerintah Kota setempat.

Dalam pelaksanaannya bank sampah Maspro Mesra memerlukan waktu yang cukup panjang untuk menekan volume sampah agar berkurang dari tahuntahun sebelum didirikannya bank sampah. Berikut adalah perkembangan volume sampah sejak tahun 2010 hingga tahun 2015 yang masuk ke TPA Kota Probolinggo.

Tabel 4.1 Volume Sampah Tahun 2010 hingga 2015

\begin{tabular}{cccc}
\hline No. & Tahun & Jumlah volume Sampah $\left.\mathbf{( m}^{\mathbf{3}}\right)$ & $\begin{array}{c}\text { Persentase } \\
\text { sampah/ hari }\end{array}$ \\
\hline 1. & 2010 & $70.726 \mathrm{~m}^{3}$ & $193 / \mathrm{hr}$ \\
$\mathbf{2 .}$ & 2011 & $63.942 \mathrm{~m}^{3}$ & $174 / \mathrm{hr}$ \\
$\mathbf{3 .}$ & 2012 & $57.256 \mathrm{~m}^{3}$ & $156 / \mathrm{hr}$ \\
$\mathbf{4 .}$ & 2013 & $61.802 \mathrm{~m}^{3}$ & $169 / \mathrm{hr}$ \\
$\mathbf{5 .}$ & 2014 & $68.291 \mathrm{~m}^{3}$ & $187 / \mathrm{hr}$ \\
$\mathbf{6 .}$ & 2015 & $76.328 \mathrm{~m}^{3}$ & $209 / \mathrm{hr}$ \\
\hline
\end{tabular}

Sumber: Dokumentasi Badan Lingkungan Hidup Kota Probolinggo Tahun 2010-2015

Berdasarkan data volume sampah di atas dapat dilihat perkembangan jumlah volumenya dari tahun 2011 hingga 2015. Dimana sebelum berdirinya bank sampah di Kota Probolinggo yaitu pada tahun 2010 sampah yang masuk ke Tempat Pembuangan Akhir (TPA) sebanyak $70.726 \mathrm{~m}^{3}$. Namun tahun berikutnya mengalami penurunan jumlah sampah yaitu menjadi $63.942 \mathrm{~m}^{3}$. Perumahan adalah penyumbang volume sampah terbesar di Kota Probolinggo.

Pada tahun 2012 volume sampah turun hingga menempati angka sebesar $57.257 \mathrm{~m}^{3}$. Namun pada 2013, 2014 hingga 2015 sampah kembali mengalami kenaikkan volume hingga mencapai $76.328 \mathrm{~m}^{3}$ di tahun 2015. Tentunya ini menjadi tugas pemerintah Kota Probolinggo, masyarakat dan instansi terkait dalam penanganan dan pengelolaan sampah sehingga volume sampah yang masuk ke TPA tidak semakin membludak angkanya dari tahun ke tahun. Karena jika volume sampah terus mengalami kenaikkan akan dikhawatirkan mengganggu kegiatan ekonomi di Kota Probolinggo. 
Tabel 4.2 Rekapitulasi Sampah Masuk di Bank Sampah Maspro Mesra Kota Probolinggo Tahun 2015

\begin{tabular}{|c|c|c|}
\hline No. & Bulan & Jumlah Sampah (Ton) \\
\hline 1. & Januari & 2,5 \\
\hline 2. & Februari & 2,1 \\
\hline 3. & Maret & 2,1 \\
\hline 4. & April & 1,7 \\
\hline 5. & Mei & 1,3 \\
\hline 6. & Juni & 2,3 \\
\hline 7. & Juli & 0,5 \\
\hline 8. & Agustus & 2,9 \\
\hline 9. & September & 2,6 \\
\hline 10. & Oktober & 2,3 \\
\hline 11. & November & 2,2 \\
\hline 12. & Desember & 2,0 \\
\hline
\end{tabular}

Sumber: Dokumentasi UPT. Pengolahan Sampah dan Limbah Kota Probolinggo Tahun 2015

Tabel 4.3 Rekapitulasi Sampah Keluar di Bank Sampah Maspro Mesra Kota Probolinggo Tahun 2015

\begin{tabular}{|c|c|c|}
\hline No. & Bulan & Jumlah Sampah (Ton) \\
\hline 1. & Januari & 1,2 \\
\hline 2. & Februari & 2,7 \\
\hline 3. & Maret & 1,9 \\
\hline 4. & April & 1,5 \\
\hline 5. & Mei & 1,2 \\
\hline 6. & Juni & 1,8 \\
\hline 7. & Juli & 0,6 \\
\hline 8. & Agustus & 2,1 \\
\hline 9. & September & 2,1 \\
\hline 10. & Oktober & 1,2 \\
\hline 11. & November & 1,1 \\
\hline 12. & Desember & 1,0 \\
\hline
\end{tabular}

Sumber: Dokumentasi UPT. Pengolahan Sampah dan Limbah Kota Probolinggo Tahun 2015

Berdasarkan perbandingan kedua tabel di atas menunjukkan volume sampah anorganik yang masuk dan keluar bank sampah Maspro Mesra akan dikelola kembali (recycle) menjadi berkurang volumenya saat sampah tersebut sudah dikelola bank sampah tersebut. Seperti yang dapat kita lihat yaitu volume sampah anorganik masuk pada bulan Januari 2015 sebesar 2,5 ton kemudian dikelola menjadi 1,2 ton. Biasanya sampah yang masuk tersebut dikelola oleh UPT. PPSL dimana untuk jenis sampah anorganik seperti plastik dan botol plastik akan dicacah menjadi butiran cacahan yang nantinya dijual ke pengepul.

Penerapan konsep 3R di Kota Probolinggo berjalan cukup baik, masyarakat sebagai nasabah melakukan pemilahan sampah untuk sampah anorganik dan pembuatan kompos dari sampah organik. Pemerintah Kota Probolinggo aware terhadap kebersihan lingkungan masyarakat melalui pengelolaan sampah. Hal ini terbukti dari bantuan mesin pencacah sampah organik seperti daun, sayuran, ranting dan lain-lain yang disediakan oleh Pemerintah Kota Probolinggo di beberapa titik pantau seperti di Perumahan Asabri. Disana terdapat gedung/ tempat mesin pencacah disediakan, kemudian ada petugas yang bersedia melayani masyarakat dalam pembuatan kompos dari sampah yang mereka kumpulkan. Biasanya masyarakatmengumpulkan minimal lima sak sampah organik. 
Bank sampah di Kota Probolinggo mendapatkan bentuk partisipasi dalam pengambilan manfaat. Dimana masyarakat mendapatkan hasil pelaksanaan program bank sampah dengan konsep 3R yang diterapkan oleh bank sampah unit maupun cabang d Kota Probolinggo. Dari rangkaian rencana program bank sampah, pembuatan strategi dan penyususnan kepanitiaan serta anggaran pada suatu kegiatan oleh UPT. PSL masyarakat Probolinggo sudah bisa merasakan manfaatnya. Yaitu dari segi ekonomi dimana masyarakat mendapatkan tambahan ekonomi dari sampah yang dipilah dan ditabungkan ke bank sampah. Selain itu dari sisi lingkungan juga masyarakat mendapatkan dampak positif karena lingkungan mereka semakin bersih. Tentunya manfaat tadi merupakan dampak postif dari program bank sampah dengan konsep 3R yang diselenggarakan Pemerintah Kota Probolinggo melalui UPT.PSL Kota Probolinggo.

\section{KESIMPULAN}

Pengelolaan bank sampah di Kota Probolinggo sudah dilaksanakan dengan baik. Kinerja bank sampah Maspro Mesra di Kota Probolinggo sudah berjalan dengan baik. Namun belum mencapai hasil yang maksimal. Hal ini dikarenakan program bank sampah belum mencapai ke pelosok-pelosok daerah/ desa. Sehingga hanya pihak-pihak tertentu yang mengetahui adanya kegiatan tersebut. Masyarakat juga hanya sebatas mengurangi sampah (reduce), belum sampai pada tahap menggunakan ulang (reuse) bahkan pada proses mendaur ulang (recycle). Hanya beberapa pihak saja yang telah melakukan pada tahap recycle yaitu ibu-ibu yang bergabung dalam komunitas PAPESA dari PKK di lingkungan mereka masingmasing. Namun demikian, minimnya proses sosialisasi yang dilakukan oleh BLH dan Pemerintah Kota Probolinggo terhadap pengenalan program bank sampah kepada masyarakat umum. Untuk daerah pedesaan yang berlokasi lebih jauh dari pusat kota kurang mendapatkan sosialisasi sehingga masyarakat yang tinggal di pedesaan masih kurang peduli terhadap pengelolaan sampah dan kebersihan lingkungan oleh karenanya perlu didirikannya Koperasi Bank Sampah untuk lebih mendukung kegiatan ekonomi kerakyatan bagi masyarakat Kota Probolinggo. Selain itu dibutuhkannya program-program yang bertujuan menjaring minat masyarakat untuk ikut bergabung menjadi nasabah bank sampah. Pemerintah Kota seharusnya memasukkan kurikulum pendidikan tentang konsep 3R dalam pengelolaan dan penanganan sampah ke semua sekolah yang ada di Kota Probolinggo sehingga pengenalan pengelolaan sampah dan kelestarian lingkungan sudah ditanamkan sedini mungkin disamping itu perlu tambahan personil petugas pengangkut sampah dari rumah masyarakat untuk dibawa ke UPT. PSL Kota Probolinggo. Bagi Masyarakat Lebih aktif dan berpartisipasi dalam penangan sampah dengan konsep 3R, karena tugas menjaga kelestarian bukan hanya menjadi tanggung jawab pemerintah dan petugas bersangkutan melainkan menjadi tugas masyarakat juga. Perlu kesadaran tinggi dalam memperlakukan sampah. konsep 3R harus benar-benar diterapkan sedini mungkin dan dari lingkungan rumah sendiri.

\section{DAFTAR RUJUKAN}

Badan Lingkungan Hidup Kota Probolinggo. 2010-2015

Dwiningrum, Siti Irene Astute. 2001. Desentralisasi Dan Partisipsi Masyarakat Dalam Pendidikan. Yogyakarta: Pustaka Pelajar. 
Ghony, M. Djunaedi \& Almanshur, Fauzan. 2012. Metode Penelitian Kualitatif. Jogjakarta: Ar-Ruzz Media.

Herdiansyah, Haris. 2010. Metode Penelitian Kualitatif untuk Ilmu-ilmu Sosial. Jakarta: Salemba Humanika.

Ndraha, Taqliziduhu. 1990. Pembangunan Masyarakat. Jakarta: Rineka Cipta.

Peraturan Menteri Negara Lingkungan Hidup Republik Indonesia No.18 Tahun 2008 tentang Pengelolaan Sampah. Jaringan Dokumentasi dan Informasi Hukum Menteri Lingkungan hidup (Online), (http://www.menlh.go.id /DATA/UU18-2008.pdf), diakses 18 September 2015.

Peraturan Menteri Negara Lingkungan Hidup RI No.13 Tahun 2012 tentang Pedoman Pengelolaan Reduce, Reuse dan Recycle Melalui Bank Sampah. Jaringan Dokumentasi dan Informasi Hukum Menteri Lingkungan hidup (Online), diakses 18 September 2015.

Peraturan Pemerintah RI No. 81 Tahun 2012 Tentang Pengelolaan Sampah Rumah Tangga Dan Sampah Sejenis Sampah Rumah Tangga. Menteri Lingkungan Hidup (Online), https://www.menlh.go.id/DATA/PP_NO_81_ TAHUN_2012.pdf), diakses 18 September 2015.

Perda Kota Probolinggo Nomor 5 Tahun 2010 tentang Pengelolaan Sampah

Peraturan Walikota Probolinggo Nomor 3 tentang Petunjuk Pelaksanaan Pengelolaan Sampah.

Puspitawati, Yuni \& Rahdriawan, Mardwi. 2012. Kajian Pengelolaan Sampah Berbasis Masyarakat dengan Konsep 3R (Reduce, Reuse, Recycle) di Kelurahan Larangan Kota Cirebon. Jurnal Pembangunan Wilayah \& Kota. 8 (4): 349-359

Slamet, Y. 1994. Pembangunan Masyarakat Berwawasan Partisipasi. Surakarta: Sebelas Maret University Press.

Slamet, J.S 2000. Kesehatan lingkungan. Jogjakarta: Gajah Mada University Pers.

Sondang,P. Siagian. 1985. Administrasi Pembangunan. Jakarta: Bumi Aksara.

UPT Pengolahan Sampah dan Limbah Kota Probolinggo tahun 2015

Wijaya, Pandu Sukma. 2014. Implementasi Program Bank Sampah Malang (BSM) dalam Pemberdayaan Ekonomi Masyarakata Kelurahan Sukun Kota Malang. Skripsi Tidak Diterbitkan. Malang: FE UM. 